\title{
DEP Domain-Containing Protein 1A
}

National Cancer Institute

\section{Source}

National Cancer Institute. DEP Domain-Containing Protein 1A. NCI Thesaurus. Code C126131.

DEP domain-containing protein $1 \mathrm{~A}(811 \mathrm{aa}, \sim 93 \mathrm{kDa})$ is encoded by the human DEPDC1 gene. This protein is involved in the negative regulation of transcription. 